\section{Remontant Flowering Potential of Ten Hydrangea macrophylla (Thunb.) Ser. Cultivars}

\author{
Jeffrey A. Adkins ${ }^{1}$ and Michael A. Dirr ${ }^{2}$ \\ Department of Horticulture,The University ofGeorgia,Athens, GA30602-7273
}

Additional index words. floral induction, photoperiod, temperature

\begin{abstract}
Floral induction of 10 Hydrangea macrophylla (Thunb.) Ser. cultivars ('All Summer Beauty', 'Dooley', 'Endless Summer', 'Générale Vicomtesse de Vibraye', 'Lilacina', 'Mariesii Variegata', 'Mme. Emile Mouillère', 'Nikko Blue', 'Penny Mac', and 'Veitchii') was evaluated to determine the remontant flowering potential. Cultivars exhibiting superior flowering potential could facilitate year-round production of florist's hydrangea and expand the geographic adaptation of hydrangeas in the landscape. Plants were tested under either 8-hour inductive short-day (SD) or 24-hour noninductive extended-day (ED) photoperiods at $24 \pm 2{ }^{\circ} \mathrm{C}$. Floral induction of $\boldsymbol{H}$. macrophylla occurred under both SD and ED but was more rapid under SD than under ED. Shoot length and total number of nodes were significantly different for cultivars, photoperiods, and harvest dates. Significant differences in the floral initiation and development were observed among cultivars. 'Penny Mac', 'Endless Summer', 'Lilacina', 'Mme. Emile Mouillère', and 'Nikko Blue' displayed significantly greater floral meristem development under SD than all other cultivars. Over the nine-week period, only 'Dooley', 'Endless Summer', and 'Penny Mac' floral development was affected significantly greater by SD photoperiods than ED photoperiods. All others cultivars showed similar floral development under SD and ED. Stage of meristem development was highly correlated with number of nodes, but not with shoot length.
\end{abstract}

On a worldwide basis, $H$. macrophylla (Hydrangeaceae) is one of the most widely grown and marketed plants in the nursery and floriculture industries (Bailey, 1992). Two inflorescence forms of H. macrophylla exist: 1) a round, densely branched corymb with mostly sterile flowers bearing large showy sepals (mophead), and 2) a flattened corymb with numerous, densely clustered fertile flowers surrounded by fewer sterile flowers bearing showy sepals (lacecap). The majority of cultivated hydrangeas, including florist's types, have mophead inflorescences. Potted hydrangeas remain popular despite challenging production requirements and a limited market window. Physiological requirements for floral induction make year-round production cost prohibitive. Although cold susceptible, hydrangeas also remain popular flowering landscape shrubs. In temperate climates, winter temperatures below $-23^{\circ} \mathrm{C}$ and early fall or spring frosts often kill stem tissues and flower buds formed during the previous season (Adkins et al., 2002; Huxley et al., 1992). Therefore, H. macrophylla can only be grown successfully as a reliable flowering landscape shrub in U.S. Dept. of Agriculture (USDA) Hardiness Zones 6 to 9 (USDA, 1990). Decreasing temperature and daylength triggers H. macrophylla floral induction (Bailey, 1992;

Received for publication 11 Mar. 2002. Accepted for publication $15 \mathrm{Dec}$. 2002. This paper is a portion of a thesis submitted in partial fulfillment of a Master of Science degree. We thank Douglas Bailey and Glenn Ware for their technical and statistical assistance.

${ }^{1}$ Graduate Research Assistant. Current address: Dept. of Horticultural Science, NC State Univ., Raleigh, NC 27695-7609.

${ }^{2}$ Professor.

HortScience, Vol. 38(7), DeCember 2003 flowering, as used here, indicates continuous flowering throughout the growing season. Remontant flowering cultivars should be less dependent on photoperiod and temperature for floral induction. 'All Summer Beauty', 'Dooley', 'Endless Summer', 'Forever Pink', 'Générale Vicomtesse de Vibraye', 'Mme. Emile Mouillère', 'Mousseline', 'Nikko Blue' 'Penny Mac', and 'Veitchii' are most often cited as remontant flowering hydrangea cultivars (Dirr, 1999; Haworth-Booth, 1984; Lawson-Hall and Rothera, 1995). Remontant flowering cultivars could facilitate year-round potted hydrangea production by reducing or eliminating the need for costly inputs. Additionally, remontant flowering cultivars would expand the geographical range of $H$. macrophylla cultivation by providing reliable flowering in more northerly areas or areas prone to untimely frosts.

The objective of this study was to assess variation in requirements for floral induction among several $H$. macrophylla cultivars. We hypothesized that cultivars differed in their production of flowers during exposure to either inductive or noninductive conditions. Also, we expected remontant flowering cultivars to develop more advanced floral primordia than nonremontant cultivars under noninductive conditions.

\section{Materials and Methods}

Bean, 1978; Struckmeyer, 1950). Further reproductive meristem development occurs during the dormant period following induction, and shoot expansion and flowering occur in early spring and summer, respectively (Struckmeyer, 1950). Pot plant producers rely on naturally occurring photoperiods and temperatures in the summer and fall for vegetative growth and floral induction, respectively. Dependence on these seasonal conditions limits marketing of flowering plants to spring sales.

In order to investigate the potential for yearround production, research on the influence of photoperiod, temperature, light intensity, and chemical growth regulators on floral induction and development has been conducted (Bailey and Weiler, 1984; Bailey et al., 1986; Litlere and Strømme, 1975; Vidalie, 1986). Temperature and photoperiod have a pronounced effect on floral induction and development. Experiments using several $H$. macrophylla genotypes established the following relationships: 1) at mean daily temperatures $>22{ }^{\circ} \mathrm{C}$, 8- to 12 -h photoperiods are inductive whereas photoperiods $>16 \mathrm{~h}$ are noninductive; and 2) temperatures around $18{ }^{\circ} \mathrm{C}$ are inductive regardless of photoperiod (Bailey and Weiler, 1984; Litlere and Strømme, 1975). Bailey and Weiler (1984) reported a protocol for out of season hydrangea production using artificial lighting and controlled temperature regimes. However, production success is cultivar dependent and requires photoperiod manipulation at specific growth stages. All cultivars tested require inductive conditions as outlined above for optimum floral development.

Several H.macrophylla cultivars have been recognized as remontant flowering based on landscape observations. The term remontant
Stock plants grown in 11.8-L plastic containers were maintained outdoors under shadecloth (45\% transmittance). Plants were topdressed twice per year with $17 \mathrm{~N}-3 \mathrm{P}-6.7 \mathrm{~K}$ with micronutrients (Nutricote; Florikan, Sarasota, Fla.) at $65 \mathrm{~g} /$ container. All plants were overhead irrigated as needed. Single-node cuttings from stock plants were rooted in 7.6 $\times 7.6 \times 8.9-\mathrm{cm}$ propagation cells in Aug. and Sept. 1999. Cuttings were dipped for $5 \mathrm{~s}$ in $0.1 \%$ indole-3-butyric acid-potassium salt (KIBA) and placed in 3 perlite : 1 peat (v:v) medium under intermittent mist. After rooting, plants were transferred to a greenhouse bench, fertilized with $7 \mathrm{~g}$ Nutricote $17 \mathrm{~N}-3 \mathrm{P}-6.7 \mathrm{~K}$ with micronutrients per cell and fertilized weekly with a solution of $20 \mathrm{~N}-4.4 \mathrm{P}-16.6 \mathrm{~K}$ at $200 \mathrm{mg} \cdot \mathrm{L}^{-1} \mathrm{~N}$ (Peters $20-10-20$ Peat-Lite Special; Scotts-Sierra Hort. Prod. Co., Marysville, Ohio). The experiment was conducted in a glass greenhouse with ambient air temperatures monitored by a computer-interfaced aspirated air temperature sensor and data collected at $\approx 1$-min intervals (Q-COM Corp., Irvine, Calif.). All plants were maintained under a $24-\mathrm{h}$ photoperiod $\left(1.44 \mu \mathrm{mol} \cdot \mathrm{m}^{-2} \cdot \mathrm{s}^{-1}\right.$ irradiation provided by $60 \mathrm{~W}$ incandescent bulbs) until treatments began. An average daily temperature of $24 \pm 2{ }^{\circ} \mathrm{C}$ was maintained throughout the study.

Seven mophead cultivars ("All Summer Beauty', 'Dooley', 'Endless Summer', 'Générale Vicomtesse de Vibraye', 'Mme. Emile Mouillère', 'Nikko Blue', and 'Penny Mac') and three lacecap cultivars ('Lilacina', 'Mariesii Variegata', and 'Veitchii') were used in this study. All plants have blue to pink flowers, depending on the availability 


\section{Crop Production}

of aluminum in the medium, except 'Mme. Emile Mouillère', which bears white flowers. On 5 Jan. 2000, 48 plants of each cultivar were pinched to two nodes and transplanted into 3.65-L containers filled with 6.25 parts milled pine bark : 1 part sand (v/v) and amended with $1 \mathrm{~kg} \cdot \mathrm{m}^{-3}$ gypsum. Slow-release fertilizer was incorporated at $4.5 \mathrm{~kg} \cdot \mathrm{m}^{-3}$ (Osmocote $24 \mathrm{~N}-$ 1.8P-5.8K, Scotts-Sierra Hort. Prod. Co.) and micronutrients (Micromax, Scotts-Sierra Hort. Prod. Co.) at $0.9 \mathrm{~kg} \cdot \mathrm{m}^{-3}$. To control fire ants, bifenthrin (Talstar; FMC Corp., Philadelphia) was incorporated at $0.9 \mathrm{~kg} \cdot \mathrm{m}^{-3}$. All plants were placed on greenhouse benches under a 24-h photoperiod, watered by hand and maintained with standard nursery practices throughout the experiment. On 11 Feb., two shoots per plant were pinched to two nodes bearing vegetative axillary buds, and all other shoots were removed. On 24 Mar., 36 plants per cultivar with three to five, fully expanded leaf pairs per shoot were selected at random. Twelve plants per cultivar were placed on one of three greenhouse benches covered with shadecloth (45\% transmittance).

The experimental design was a split-split plot design with three benches as blocks, two photoperiods per block, and three harvest dates per photoperiod per block. Treatments, beginning on 24 Mar. 2000, consisted of an 8-h SD photoperiod or 24-h ED photoperiod. Black cloth with aluminum sheathing was pulled over all three benches daily at $1700 \mathrm{HR}$ and removed at 0900 HR. To achieve a 24-h photoperiod, $1.44 \mu \mathrm{mol} \cdot \mathrm{m}^{-2} \cdot \mathrm{s}^{-1}$ irradiation was provided by $60 \mathrm{~W}$ incandescent bulbs from 1700 HR until 0900 HR. To prevent iron deficiency, $0.46 \mathrm{~kg} \cdot \mathrm{L}^{-1}$ monosodium ferric-diethylenetriamine pentaacetate (Sequestrene $330 \mathrm{Fe}$; Becker-Underwood, Ames, Iowa) was applied to growing medium on 27 Mar. and 28 May. One stem from each of six plants per cultivar was randomly harvested from each treatment at 3,6, and 9 weeks after 24 Mar. Stem length and total node numbers present were recorded. Apical buds were dissected under a light microscope and the stage of floral development was determined (Fig. 1). Analysis of variance (ANOVA) was conducted on all data using SAS systems General Linear Model procedure and appropriate denominators (SAS Institute, 1996). Mean separation was computed where appropriate using protected least significant differences at $P \leq 0.05$.

\section{Results}

Block effects were not significant for any dependent variables, therefore data from each block were combined (Table 1). A photoperiod by harvest interaction was present for shoot length while all other interactions were non significant at $P \leq 0.05$ (Table 1). Cultivar data were combined over all harvest dates since no significant interactions were detected between cultivar and harvest date at $P \leq 0.05$ (Table 1). There were significant differences between cultivars for floral development stage, shoot length, and number of nodes (Table 2). For instance, floral meristems of 'Penny Mac', 'Mme. Emile Mouillère', 'Lilacina', and

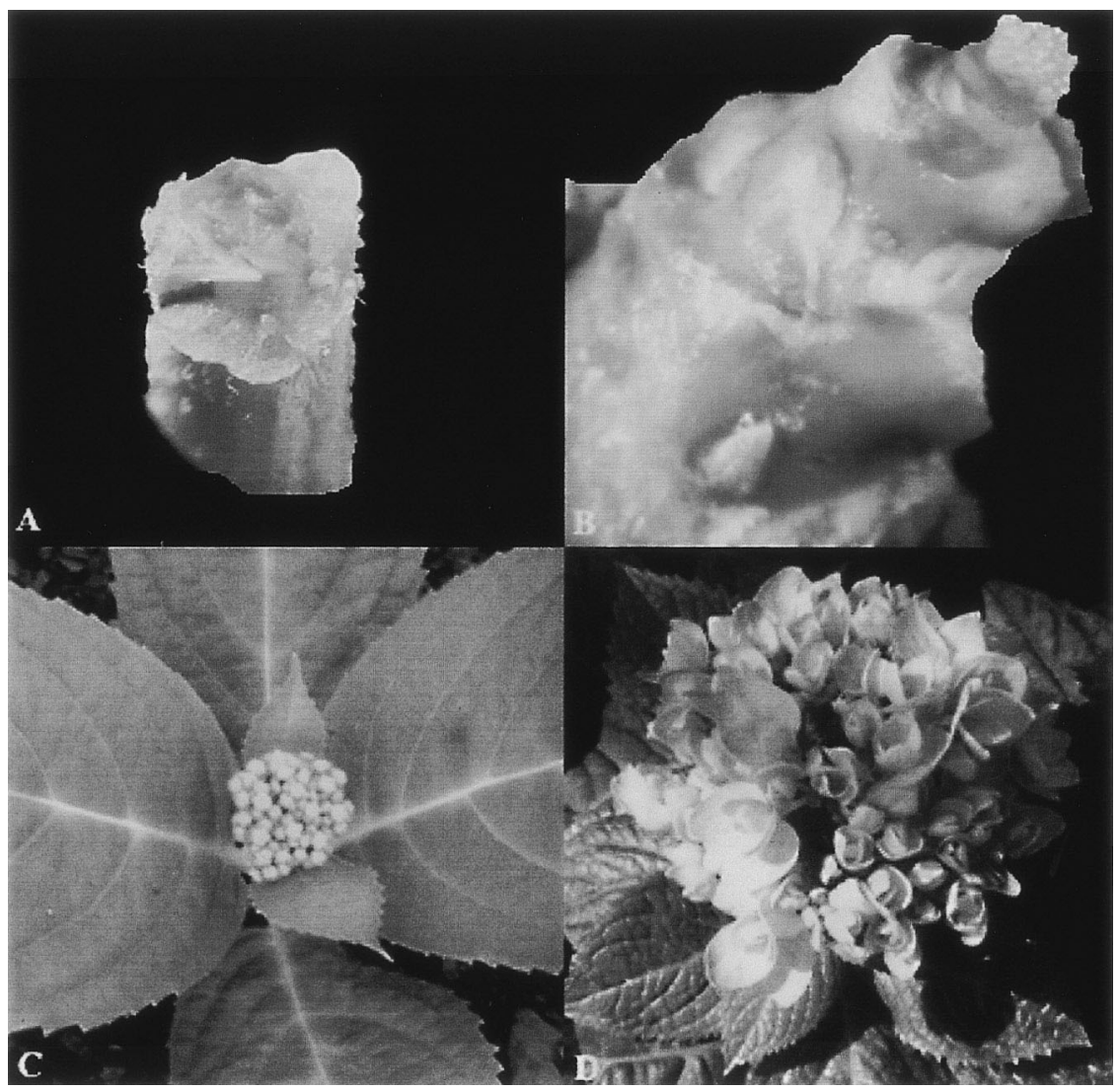

Fig. 1. Stages of apical meristem development for Hydrangea macrophylla. (A) stage 1: meristem vegetative (no flower primordia distinguishable) (B) stage 2: meristem reproductive (one to many flower primordia clearly distinguishable) (C) stage 3: visible flower bud (floral bud visible to the naked eye without removal of leaves or leaf primordia) (D) stage 4: one to many florets open with pigmentation developing.

Table 1. Analysis of variance for flower developmental stage (Stage), shoot length (Shoot), and number of nodes (Nodes) for 10 hydrangea cultivars.

\begin{tabular}{lrccc}
\hline & & \multicolumn{3}{c}{ Mean squares } \\
\cline { 3 - 5 } Source & df & Stage & Shoot $(\mathrm{cm})$ & Nodes \\
\hline Block (Blk) & 2 & $3^{\text {Ns }}$ & $141^{\text {Ns }}$ & $1^{\text {Ns }}$ \\
Photoperiod (P) & 1 & $25^{*}$ & $2805^{*}$ & $4^{*}$ \\
Error = Blk $\times \mathrm{P}$ & & & & \\
Harvest $(\mathrm{H})$ & 2 & $12^{*}$ & $1325^{*}$ & $38^{*}$ \\
$\mathrm{P} \times \mathrm{H}$ & 2 & $2^{\mathrm{Ns}}$ & $148^{*}$ & $2^{\mathrm{Ns}}$ \\
Error $=\mathrm{Blk} \times \mathrm{P} \times \mathrm{H}$ & & & & \\
Cultivar $(\mathrm{C})$ & 9 & $13^{*}$ & $193^{*}$ & $63^{*}$ \\
$\mathrm{C} \times \mathrm{P}$ & 9 & $1^{\mathrm{Ns}}$ & $20^{\mathrm{Ns}}$ & $16^{\mathrm{Ns}}$ \\
$\mathrm{C} \times \mathrm{H}$ & 18 & $1^{\mathrm{Ns}}$ & $19^{\mathrm{Ns}}$ & $12^{\mathrm{Ns}}$ \\
$\mathrm{C} \times \mathrm{P} \times \mathrm{H}$ & 18 & $1^{\mathrm{Ns}}$ & $7^{\mathrm{Ns}}$ & $7^{\mathrm{Ns}}$ \\
Error $=\mathrm{Blk} \times \mathrm{P} \times \mathrm{H} \times \mathrm{C}$ & & & & \\
\hline
\end{tabular}

Ns, ${ }^{*}$ Nonsignificant or significant at $P \leq 0.05$.

'Endless Summer' were significantly more advanced than those of 'Générale Vicomtesse de Vibraye', 'All Summer Beauty', 'Dooley', 'Veitchii', and 'Mariesii Variegata' (Table 2). Shoots of 'Penny Mac' and 'Mme. Emile Mouillère' were longer than all other cultivars except 'Nikko Blue' and 'Générale Vicomtesse de Vibraye', while 'Mariesii Variegata' and 'Lilacina' had significantly shorter shoots than all other cultivars (Table 2). A significant negative linear correlation existed between stage of development and number of nodes (Fig. 2). For example, 'Penny Mac', 'Lilacina', and 'Endless Summer' had significantly fewer nodes than 'Générale Vicomtesse de Vibraye', 'All Summer Beauty', 'Dooley',
'Veitchii', and 'Mariesii Variegata' (Table 2). In contrast, there was not a significant correlation between stage of development and shoot length (data not shown).

Under short-day (SD) conditions and over all three harvest dates, 'Penny Mac', 'Endless Summer', 'Lilacina', 'Mme. Emile Mouillère', and 'Nikko Blue' had significantly more advanced floral meristems than all other cultivars (Table 3 ). Less variation in meristem development was observed under extendedday (ED) conditions, but 'Penny Mac', 'Endless Summer', 'Lilacina', and 'Mme. Emile Mouillère' exhibited more advanced floral development than 'Mariesii Variegata', 'Dooley', or 'Veitchii' (Table 3). Although at 
Table 2. Variation in stage of floral development, shoot length, and number of nodes among 10 hydrangea cultivars. Data represent averages over both photoperiods and all three harvest dates.

\begin{tabular}{lccc}
\hline Cultivar & $\begin{array}{c}\text { Floral } \\
\text { development stage }\end{array}$ & $\begin{array}{c}\text { Shoot } \\
\text { length }(\mathrm{cm})\end{array}$ & $\begin{array}{c}\text { No. } \\
\text { nodes }\end{array}$ \\
\hline Penny Mac & $2.7 \mathrm{a}^{\mathrm{y}}$ & $14.7 \mathrm{a}$ & $7.3 \mathrm{~cd}$ \\
Mme. Emile Mouillère & $2.7 \mathrm{a}$ & $14.9 \mathrm{a}$ & $8.8 \mathrm{bc}$ \\
Lilacina & $2.6 \mathrm{ab}$ & $7.8 \mathrm{c}$ & $6.6 \mathrm{~d}$ \\
Endless Summer & $2.5 \mathrm{ab}$ & $11.9 \mathrm{~b}$ & $7.8 \mathrm{~cd}$ \\
Nikko Blue & $2.1 \mathrm{bc}$ & $13.5 \mathrm{ab}$ & $8.8 \mathrm{bc}$ \\
Générale Vicomtesse de Vibraye & $1.7 \mathrm{~cd}$ & $13.5 \mathrm{ab}$ & $9.6 \mathrm{ab}$ \\
All Summer Beauty & $1.6 \mathrm{~d}$ & $12.4 \mathrm{~b}$ & $10.1 \mathrm{ab}$ \\
Dooley & $1.4 \mathrm{~d}$ & $12.1 \mathrm{~b}$ & $10.0 \mathrm{ab}$ \\
Veitchii & $1.3 \mathrm{~d}$ & $11.9 \mathrm{~b}$ & $9.8 \mathrm{ab}$ \\
Mariesii Variegata & $1.3 \mathrm{~d}$ & $8.9 \mathrm{c}$ & $10.7 \mathrm{a}$ \\
\hline
\end{tabular}

${ }^{2}$ Stages of apical meristem development for Hydrangea macrophylla. Stage 1: meristem vegetative (no flower primordia distinguishable). Stage 2: meristem reproductive (one to many flower primordia clearly distinguishable). Stage 3: visible flower bud (floral bud visible to the naked eye without removal of leaves or leaf primordia). Stage 4: one to many florets open with pigmentation developing.

${ }^{y}$ Mean separation within columns by least significant differrence at $P \leq 0.05$.

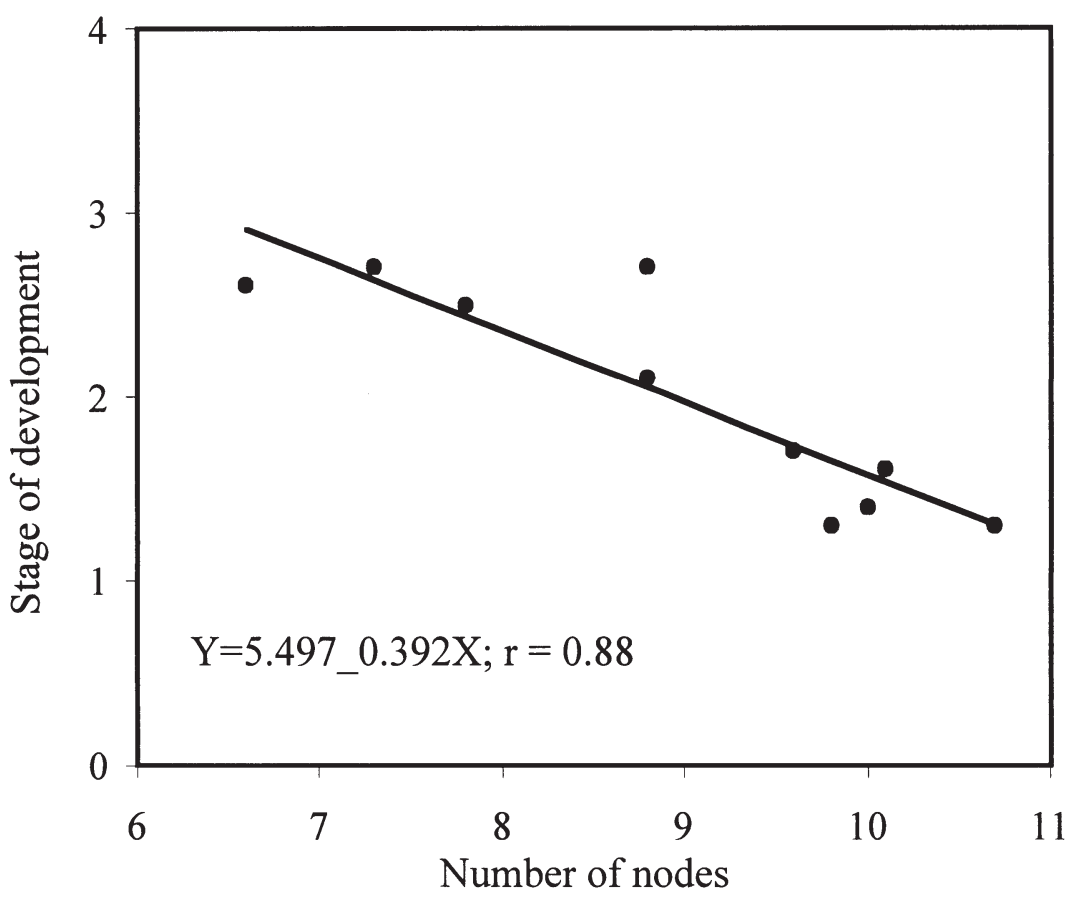

Fig. 2. Relationship between stage of meristem development and number of nodes in 10 hydrangea cultivars. Data were averaged over both photoperiods and all three harvest dates.

least one plant of each cultivar developed floral primordia (data not shown), 'All Summer Beauty', 'Générale Vicomtesse de Vibraye', 'Mariesii Variegata', 'Dooley', and 'Veitchii' remained primarily vegetative over the 9 -week study period under ED.

\section{Discussion}

We have demonstrated variation in flowering potential among ten $H$. macrophylla genotypes under two different photoperiods. The significant genotypic variation among $H$. macrophylla cultivars observed in this experiment has implications for breeders developing new cultivars for nursery and greenhouse production. Limited floral induction and developmental rates of $H$. macrophylla cultivars reported by other researchers may be due to the use of cultivars specifically selected for controlled flowering under greenhouse conditions (Bailey and Weiler, 1984; Litlere and Strømme, 1975). Accelerated floral induction and development under SD was expected and has been reported previously for $H$. macrophylla (Bailey, 1983; Litlere and Strømme, 1975).

There are over 500 extant $H$. macrophylla cultivars representing a large pool of untested genotypes (Dirr, 1999; Haworth-Booth, 1984). Haworth-Booth(1984) identified 12 remontant flowering cultivars based on extensive outdoor evaluations in Surrey, England. Shanks (1985) suggested that some $H$. macrophylla cultivars in the landscape may initiate flowers as early as August if stems remain unpinched, and that sensitivity to induction increases over time. Cultivars capable of flowering under ED photoperiods would provide flowers during the summer if induction occurs early and floral development is rapid.

Fewer numbers of nodes in cultivars with more advanced floral meristems is not unex- pected since early development of floral primordia would terminate further vegetative development. Plants capable of producing flowers on shorter stems would be more desirable for potted production by decreasing production time and reducing the need for chemical or mechanical height control. Chemical growth regulators have shown some promise in reducing flowering time in florist's hydrangea and facilitating year-round production (Bailey et al., 1986). However, the number of growth regulator applications required makes such an approach cost prohibitive. Importantly, a relationship between decreased numbers of expanded leaf pairs and early flowering has been observed in florist's hydrangeas following applications of plant growth regulators. Bailey et al. (1986) reported significantly greater floral bud development and significantly fewer expanded leaf pairs on 'Merritt's Supreme' following applications of the plant growth regulator ancymidol.

A 6- to 8- week chilling period is usually necessary to provide uniform flowering times in hydrangea (Bailey, 1989). Year-round production could significantly enhance the marketability of forced hydrangeas, but would require eliminating or significantly reducing the chilling requirement (Bailey, 1983; Shanks, 1981). The current method for year-round production relies on manipulation of photoperiod and temperature to induce floral bud development followed by greenhouse forcing (Bailey, 1989). By using remontant flowering genotypes, the requirements to manipulate greenhouse conditions could be reduced or eliminated thereby lowering the overall cost of production. The florist's hydrangea market could be further enhanced if garden worthy cultivars were used in floriculture production. However, inflorescences developed without a dormant period may be smaller than those produced under traditional production protocols. The dormant period allows further development of the inflorescence and subsequently increases inflorescence size.

This study has shown that requirements for floral induction and development are cultivar dependent. Hydrangea macrophylla is not an obligate SD plant for floral induction, and SD photoperiods at $24{ }^{\circ} \mathrm{C}$ are not required for induction of all cultivars. These conditions do enhance floral meristem development and synchronize flowering time of some cultivars. Container-grown 'Mme. Emile Mouillère', 'Penny Mac', and 'Endless Summer' readily initiated floral primordia and developed mature inflorescences during the summer months when grown outdoors in Athens, Ga. (personal observation). Flowering is also extended on these cultivars when compared with other cultivars growing in similar conditions. In fact, 'Endless Summer' has produced flowers into late Oct. in Athens, Ga. after many $H$. macrophylla cultivars had defoliated (personal observation). On 11 Sept. 1998, H. macrophylla 'Endless Summer' was observed in full flower at Bailey Nurseries St. Paul, Minn. where it has been growing and flowering reliably in their trial plots for the last ten years (Dirr, 1999). Because 
Table 3. Stage of meristem development for 10 hydrangea cultivars after exposure to short-day (SD) or extendedday (ED) photoperiod at $24 \pm 2{ }^{\circ} \mathrm{C}$. Six stems from six plants per cultivar were evaluated at three harvest times and data were pooled over all harvest times $(3,6$, and 9 weeks).

\begin{tabular}{llc}
\hline & \multicolumn{2}{c}{ Photoperiod } \\
\cline { 2 - 3 } Cultivar & SD & ED \\
\hline Penny Mac & $3.1^{\mathrm{z}} \mathrm{a}^{\mathrm{y}}$ & $2.3 \mathrm{ab}$ \\
Endless Summer & $3.1 \mathrm{a}$ & $2.1 \mathrm{abc}$ \\
Lilacina & $3.0 \mathrm{a}$ & $2.2 \mathrm{ab}$ \\
Mme. Emile Mouillère & $2.7 \mathrm{a}$ & $2.6 \mathrm{a}$ \\
Nikko Blue & $2.5 \mathrm{a}$ & $1.8 \mathrm{bcd}$ \\
All Summer Beauty & $1.9 \mathrm{~b}$ & $1.3 \mathrm{~cd}$ \\
Générale Vicomtesse de Vibraye & $1.8 \mathrm{~b}$ & $1.6 \mathrm{bcd}$ \\
Mariesii Variegata & $1.4 \mathrm{~b}$ & $1.2 \mathrm{~d}$ \\
Dooley & $1.7 \mathrm{~b}$ & $1.1 \mathrm{~d}$ \\
Veitchii & $1.4 \mathrm{~b}$ & $1.2 \mathrm{~d}$ \\
\hline
\end{tabular}

${ }^{2}$ Stages of apical meristem development for Hydrangea macrophylla. Stage 1: meristem vegetative (no flower primordia distinguishable). Stage 2: meristem reproductive (one to many flower primordia clearly distinguishable). Stage 3: visible flower bud (floral bud visible to the naked eye without removal of leaves or leaf primordia). Stage 4: one to many florets open with pigmentation developing.

${ }^{\mathrm{y}}$ Mean separation within columns by least significant difference at $P \leq 0.05$.

any aboveground stems and buds would be killed by winter temperatures in this region, it is likely that flowers developed on current season's shoots.

Using remontant flowering genotypes, flowering potential in geographic areas prone to untimely frosts would be enhanced. Colder regions (USDA Hardiness Zones 4 and 5) could thus become important markets for these H. macrophylla cultivars. Cultivars that displayed the most advanced floral primordia under noninductive (ED) conditions ('Penny
Mac', 'Endless Summer', 'Lilacina', 'Mme. Emile Mouillère' and 'Nikko Blue') exhibit the greatest potential for year-round greenhouse production or landscape use in Zone 5 and warmer climates.

\section{Literature Cited}

Adkins, J.A., M.A. Dirr, and O.M. Lindstrom. 2002. Cold hardiness potential of ten Hydrangea taxa. J. Environ. Hort. 20:171-174.

Bailey, D.A. 1983. Control of growth and flowering in hydrangea [Hydrangea macrophylla
(Thunb.) Ser.]. MS Thesis, Purdue Univ., West Lafayette, Ind.

Bailey, D.A. 1989. Hydrangea production. Timber Press, Portland, Ore.

Bailey, D.A. 1992. Hydrangeas, p. 365-383. In: R. Larson (ed.). Introduction to floriculture. 2nd ed. Academic Press, San Diego.

Bailey, D.A. and T. Weiler. 1984. Control of floral initiation in florist's hydrangea. J. Amer. Soc. Hort. Sci. 109:785-791.

Bailey, D.A., T. Weiler, and T. Kirk. 1986. Chemical stimulation of floral initiation in florists' hydrangea. HortScience 21:256-257.

Bean, W.J. 1978. Trees and shrubs hardy in the British Isles. 8th ed. Vol. II. John Murray, London.

Dirr, M.A. 1999. Opportunity exists for gardenerfriendly hydrangea. Nursery Mgt. Production 15(1):16-17, 96

Haworth-Booth, M. 1984. The hydrangeas. 5th ed. Constable and Company, London.

Huxley, A., M. Griffiths, and M. Levy. 1992. The new Royal Horticultural Society dictionary of gardening. Macmillan, London.

Lawson-Hall, T. and B. Rothera. 1995. Hydrangeas: A gardener's guide. Timber Press, Portland, Ore.

Litlere, B. and E. Strømme. 1975. The influence of temperature, daylength, and light intensity on flowering in Hydrangea macrophylla (Thunb.) Ser. Acta Hort. 51:285-298.

SAS Institute, Inc. 1996. SAS software proprietary release 6.12. SAS Institute Inc., Cary, N.C.

Shanks, J.B. 1985. Hydrangeas, p. 535-558. In: V. Ball (ed.). The Ball Red Book: Greenhouse growing. Reston Publ., Reston, Va.

Struckmeyer,E.B. 1950. Blossom bud induction and differentiation in hydrangea. Proc. Amer. Soc. Hort. Sci. 56:410-414.

U.S. Department of Agriculture (USDA). 1990. Plant hardiness zone map. U.S. Dept. of Agr., Washington, D.C. Misc. Publ. 1475.

Vidalie, H. 1986. Influence of various cold treatments on the reaction to forcing of miniature Hydrangea macrophylla. Acta Hort. 181:263-267. 